\title{
Brazing of Mn-Cu Alloy and 430 Stainless Steel with Cu-34Mn-6Ni-10Sn Filler Metal
}

\author{
Jing Yang*1, Yonggang $\mathrm{Xu}^{* 2}$, Song Zhang and Mingyue Zhang*3 \\ Key Laboratory of Advanced Technologies of Materials, School of Materials Science and Engineering, Southwest Jiaotong University, \\ Chengdu 610031, China
}

In this paper, brazing of $\mathrm{Mn}-\mathrm{Cu}$ damping alloy and 430 stainless steel (SS) using $\mathrm{Cu}-34 \mathrm{Mn}-6 \mathrm{Ni}-10 \mathrm{Sn}$ filler metal was carried out at different temperatures $\left(850^{\circ} \mathrm{C}\right.$ to $880^{\circ} \mathrm{C}$ ) for different times $(5 \mathrm{~min}$ to $12 \mathrm{~min})$. The microstructure and mechanical properties of brazed joints were investigated. The results show that a $(\mathrm{Fe}, \mathrm{Mn})$ solid solution diffusion layer was formed at the interface between $\mathrm{SS}$ and brazing seam. The brazing seam was composed of a $(\mathrm{Cu}, \mathrm{Mn})$ solid solution phase and a ( $\mathrm{Cu}, \mathrm{Mn}, \mathrm{Sn})$ solid solution phase. Besides, the needle-like $\mathrm{Mn}-\mathrm{Cr}-\mathrm{Cu}-\mathrm{Fe}$ compounds were found to distribute near the interface of each substrate and brazing seam. The grain boundary penetration of $(\mathrm{Cu}, \mathrm{Mn}, \mathrm{Sn})$ solid solution phase led to the local melting of $\mathrm{Mn}-\mathrm{Cu}$ alloy. The joint brazed at $870{ }^{\circ} \mathrm{C}$ for $10 \mathrm{~min}$ possessed the highest shear strength of about $212 \mathrm{MPa}$, the fracture occurred at the middle of brazing seam. [doi:10.2320/matertrans.M2019054]

(Received February 25, 2019; Accepted May 14, 2019; Published July 25, 2019)

Keywords: brazing, manganese-copper alloy, stainless steel, copper-based filler metal, microstructure, mechanical properties

\section{Introduction}

$\mathrm{Mn}-\mathrm{Cu}$ alloys have received much attention for their high damping capacity and mechanical properties, ${ }^{1,2)}$ and have been used for vibration and noise reduction in the fields of aerospace, automotive, nuclear industry and machinery manufacturing. ${ }^{3,4)}$ Ferritic stainless steels (SS) are widely used in industry for their good thermal conductivity, small expansion coefficient, good oxidation resistance, and excellent stress corrosion resistance. ${ }^{5)}$ Joining $\mathrm{Mn}-\mathrm{Cu}$ alloys and ferritic stainless steels can achieve the material with complementary performance and expand the application of $\mathrm{Mn}-\mathrm{Cu}$ alloy in engineering area. Considering the different chemical compositions and physical properties between $\mathrm{Mn}-\mathrm{Cu}$ alloys and SS, brazing is a suitable choice to join these two dissimilar metals. ${ }^{6,7)}$

Choosing the proper filler metal is one of the most important factors to obtain good brazed joint. Cu-based filler metals have good mechanical and wetting properties by adding alloying elements like $\mathrm{Mn}, \mathrm{Ag}, \mathrm{Ni}, \mathrm{Zn}$ and $\mathrm{Sn},{ }^{8,9)}$ and have been widely used to join copper alloys and stainless steels. According to the binary phase diagrams, $\mathrm{Mn}$ and $\mathrm{Ni}$ can completely soluble in $\mathrm{Cu}{ }^{10}$ ) The addition of $\mathrm{Mn}$ and $\mathrm{Ni}$ can improve the strength of $\mathrm{Cu}$-based filler metals. However, the addition of $\mathrm{Ni}$ can increase the melting point of filler metals and result in the increase of brazing temperature. The intermetallic compounds formed at high brazing temperature will deteriorate the mechanical performance of joint. ${ }^{11)}$ In a report, ${ }^{12)}$ the brazing of duplex stainless steels to $\mathrm{Cr}-\mathrm{Cu}$ alloy with $\mathrm{Cu}-38 \mathrm{Mn}-9.5 \mathrm{Ni}$ filler metal (AWS4764) was carried out at $1000{ }^{\circ} \mathrm{C}$. The broken pieces of stainless steel entered the liquid filler metal during brazing, the Mn-Fe phase, Mn$\mathrm{Cr}$ phase and $\mathrm{Cr}-\mathrm{Fe}$ phase were formed due to the dissolution of the base metals. Roy et al. ${ }^{13)}$ developed a $50 \mathrm{Cu}-40 \mathrm{Mn}-$ $10 \mathrm{Ni}$ filler metal by melting spinning technique to lower the

\footnotetext{
${ }^{* 1}$ Graduate Student, Southwest Jiaotong University

${ }^{* 2}$ Corresponding author, E-mail: yonggang2002@163.com

${ }^{* 3}$ Graduate Student, Southwest Jiaotong University. Present address: Key Laboratory for Advanced Technologies of Materials, School of Materials Science and Engineering, Chengdu 610031, China
}

melting point. The filler metal showed a narrow melting zone $\left(\Delta T=45^{\circ} \mathrm{C}\right)$, with solidus and liquidus temperatures at $900{ }^{\circ} \mathrm{C}$ and $945^{\circ} \mathrm{C}$, respectively. The brazing of $304 \mathrm{SS}$ and pure copper was carried out at $920^{\circ} \mathrm{C}$, a little amount intermetallic compounds were formed in the joint. In fact, to join the $\mathrm{Mn}-\mathrm{Cu}$ alloy and SS, the brazing temperature should be lower than the melting point of the $\mathrm{Mn}-\mathrm{Cu}$ alloy (about $900{ }^{\circ} \mathrm{C}$ ). Sn was confirmed to be able to reduce the melting point and improve the wettability of the filler metals. ${ }^{14)} \mathrm{Li}$ et al. ${ }^{15)}$ found that $\mathrm{Sn}$ can decrease the melting points of $\mathrm{Ag}-\mathrm{Cu}-\mathrm{Zn}-\mathrm{Sn}$ filler metals drastically. However, the excessive addition of $\mathrm{Sn}$ will increase the brittleness of filler metals owing to the formation of $\mathrm{Cu}_{41} \mathrm{Sn}_{11}$ and $\mathrm{Ag}_{3} \mathrm{Sn}$ brittle compounds. Similarly, Chatterjee et al. ${ }^{16)}$ carried out the brazing of copper alloy and mild steel with $\mathrm{Cu}-10 \mathrm{Mn}-30 \mathrm{Sn}$ filler metal at only $750{ }^{\circ} \mathrm{C}$. While the high amount of $\mathrm{Sn}$ caused the formation of $\mathrm{Fe}-\mathrm{Mn}-\mathrm{Sn}$ intermetallic compounds between the interface of mild steel and filler metal.

In this work, a $\mathrm{Cu}-34 \mathrm{Mn}-6 \mathrm{Ni}-10 \mathrm{Sn}$ filler metal was developed to join the $\mathrm{Mn}-\mathrm{Cu}$ alloy and 430SS at the temperatures below $900{ }^{\circ} \mathrm{C}$. The microstructure and melting characteristics of $\mathrm{Cu}-34 \mathrm{Mn}-6 \mathrm{Ni}-10 \mathrm{Sn}$ filler metal were studied. The microstructure and mechanical properties of $\mathrm{Mn}-\mathrm{Cu} / \mathrm{SS}$ brazed joints were investigated. And the effect of brazing temperature and time on the mechanical properties of brazed joints were also discussed.

\section{Experimental Procedures}

The $\mathrm{Mn}-\mathrm{Cu}$ alloy and 430SS were used as the substrate materials, and their chemical compositions are listed in Tables 1 and 2, respectively. The $\mathrm{Cu}-34 \mathrm{Mn}-6 \mathrm{Ni}-10 \mathrm{Sn}$ filler metal was prepared by a vacuum induction furnace, then the

Table 1 Chemical composition of $\mathrm{Mn}-\mathrm{Cu}$ alloy (mass\%).

\begin{tabular}{ccccc}
\hline $\mathrm{Cu}$ & $\mathrm{Mn}$ & $\mathrm{Al}$ & $\mathrm{Zn}$ & $\mathrm{Cr}$ \\
\hline 48.10 & 46.55 & 1.55 & 3.00 & 0.80 \\
\hline
\end{tabular}


Table 2 Chemical composition of 430SS (mass $\%$ ).

\begin{tabular}{cccccccc}
\hline $\mathrm{C}$ & $\mathrm{Si}$ & $\mathrm{Mn}$ & $\mathrm{P}$ & $\mathrm{S}$ & $\mathrm{Cr}$ & $\mathrm{Ni}$ & $\mathrm{Fe}$ \\
\hline 0.11 & 0.74 & 1.00 & 0.043 & 0.028 & 17.00 & 0.05 & Bal. \\
\hline
\end{tabular}

Table 3 Chemical composition of $\mathrm{Cu}-34 \mathrm{Mn}-6 \mathrm{Ni}-10 \mathrm{Sn}$ filler metal (mass\%).

\begin{tabular}{cccc}
\hline $\mathrm{Cu}$ & $\mathrm{Mn}$ & $\mathrm{Ni}$ & $\mathrm{Sn}$ \\
\hline 49.73 & 34.54 & 6.01 & 9.72 \\
\hline
\end{tabular}

as-cast ingot was homogenized at $720{ }^{\circ} \mathrm{C}$ for $10 \mathrm{~h}$ followed by water quenching. The chemical composition of the filler metal is given in Table 3 . To determine the liquidus temperature of the filler metal, differential scanning calorimetry (DSC, NETZSCH STA 449F3) analysis was carried out under argon atmosphere with a heating rate of $10^{\circ} \mathrm{C} / \mathrm{min}$.

For brazing, both the $\mathrm{Mn}-\mathrm{Cu}$ alloy and 430SS were cut into platelets of $30 \mathrm{~mm} \times 30 \mathrm{~mm} \times 3 \mathrm{~mm}$, and the filler metal was cut into foils with the thickness of about $300 \mu \mathrm{m}$. The surface of substrate platelets and filler metal foils were polished using various grades of $\mathrm{SiC}$ papers and then ultrasonically cleaned in ethanol solution for $10 \mathrm{~min}$. The typical sandwich brazed joint was used in the experiment, a filler metal foil was placed between $\mathrm{Mn}-\mathrm{Cu}$ alloy and SS platelets, as shown in Fig. 1(a). To remove the oxides and prevent the further oxidation of samples, the brazing flux was smeared on the contact surfaces of filler metal and substrates. Finally, the assembled sample was put in the preheated furnace. Figure 1(b) shows the schematic diagram of the brazing thermal cycle. The brazing experiment was carried out at different temperatures $(T)$ and times $(t)$, the specific experimental parameters are presented in Table 4. The brazing sample was taken out from furnace until the temperature reduced to $770{ }^{\circ} \mathrm{C}$. After cooling to room temperature, samples were cleaned in the citric acid solution.

The microstructure characterization of $\mathrm{Cu}-34 \mathrm{Mn}-6 \mathrm{Ni}-$ 10Sn filler metal and $\mathrm{Mn}-\mathrm{Cu} / \mathrm{SS}$ brazed joints were analysed by a scanning electron microscope (SEM, FEI Quanta 250)
Table 4 Processing parameters in brazing experiments.

\begin{tabular}{lll}
\hline $\begin{array}{l}\text { Brazing } \\
\text { parameters }\end{array}$ & $\begin{array}{l}\text { Brazing temperature } \\
\left(T /{ }^{\circ} \mathrm{C}\right)\end{array}$ & $\begin{array}{l}\text { Holding time } \\
(t / \mathrm{min})\end{array}$ \\
\hline & $850,860,870,880$ & 10 \\
\cline { 2 - 3 } & 870 & $5,7,10,12$ \\
\hline
\end{tabular}

equipped with an energy dispersive spectrometer (EDS). Additionally, the microhardness across the brazed joint was measured by a microhardness device (HXD-1000TM) using a load of $100 \mathrm{~g}$. Shear tests were performed on a mechanical testing machine (CMT4304) with a travel speed of 0.5 $\mathrm{mm} \cdot \mathrm{min}^{-1}$ at room temperature utilizing self-made clamp. The shear strength was calculated using the following equation: $\tau=F / A$, where $F$ is the fracture load, and $A$ is the contact area. The fracture surfaces were also observed by using SEM.

\section{Results and Discussion}

\subsection{Filler metal analysis}

Figure 2 shows the BSE image of the $\mathrm{Cu}-34 \mathrm{Mn}-6 \mathrm{Ni}-$ $10 \mathrm{Sn}$ filler metal. It can be seen that there were two phases in the filler metal. The EDS analysis results listed in Table 5 shows that these two phases were $(\mathrm{Cu}, \mathrm{Mn}, \mathrm{Ni})$ solid solution with different content of Sn. The Sn content of phase 2 was

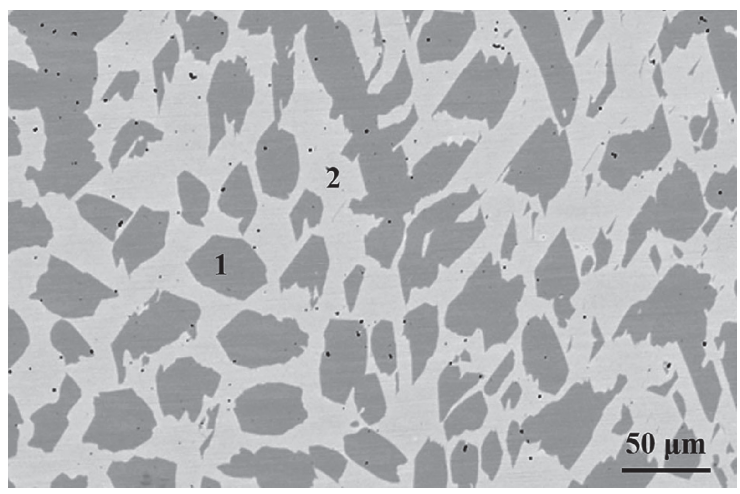

Fig. 2 BSE image of $\mathrm{Cu}-34 \mathrm{Mn}-6 \mathrm{Ni}-10 \mathrm{Sn}$ filler metal. (a)

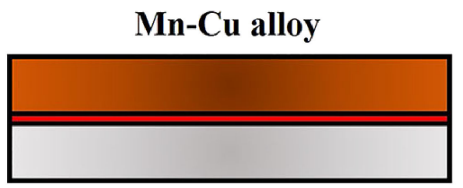

Filler metal

$430 \mathrm{SS}$

(b)

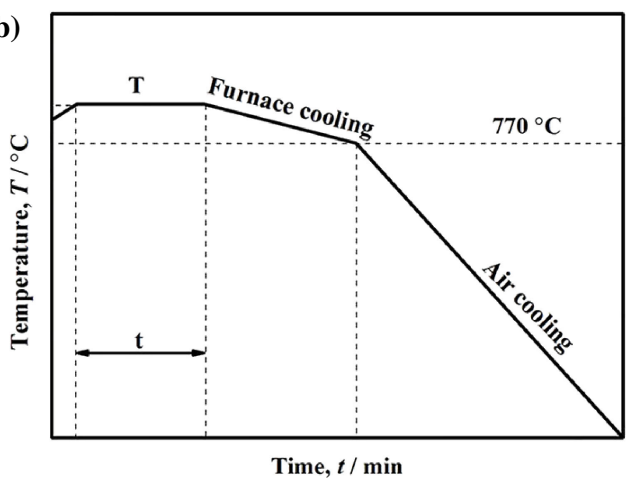

Fig. 1 (a) Schematic of brazing sample, (b) Brazing thermal cycle. 
Table 5 EDS analysis results of points marked in BSE image in Fig. 2 (mass\%).

\begin{tabular}{ccccc}
\hline Points & $\mathrm{Cu}$ & $\mathrm{Mn}$ & $\mathrm{Ni}$ & $\mathrm{Sn}$ \\
\hline 1 & 52.15 & 34.45 & 6.10 & 7.30 \\
2 & 45.54 & 33.57 & 6.12 & 14.77 \\
\hline
\end{tabular}

about twice that of phase 1, which indicated that the segregation of Sn happened during the solidification process in filler metal casting. Due to the solution strengthening effect of $\mathrm{Sn}$, the microhardness of the phase 1 and phase 2 reached $180.88 \mathrm{HV}$ and $277.05 \mathrm{HV}$, respectively.

Since $\mathrm{Sn}$ can reduce the melting point, phase 2 contained higher Sn should have a lower melting point than phase 1, theoretically. However, the DSC thermogram of the $\mathrm{Cu}-$ $34 \mathrm{Mn}-6 \mathrm{Ni}-10 \mathrm{Sn}$ filler metal has only one endothermic peak in the heating process, as shown in Fig. 3. The filler metal has a narrow melting zone, and the solidus and liquidus

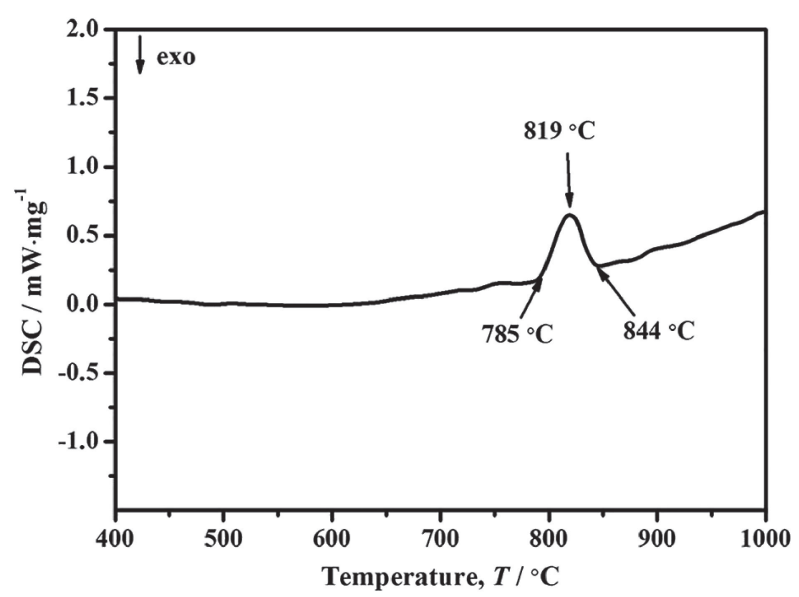

Fig. 3 DSC thermogram of $\mathrm{Cu}-34 \mathrm{Mn}-6 \mathrm{Ni}-10 \mathrm{Sn}$ filler metal. temperatures were $785^{\circ} \mathrm{C}$ and $819^{\circ} \mathrm{C}$, respectively. Based on the results of the DSC study, the brazing experiments was determined to carry out at temperatures from $850{ }^{\circ} \mathrm{C}$ (about $30{ }^{\circ} \mathrm{C}$ above the liquidus temperature) onwards.

\subsection{Microstructure of the Mn-Cu/SS brazed joints}

Figure 4(a) depicts the BSE image of the microstructure of $\mathrm{Mn}-\mathrm{Cu} / \mathrm{SS}$ joint brazed at $870{ }^{\circ} \mathrm{C}$ for $10 \mathrm{~min}$. The joint can be mainly divided into three regions: $\mathrm{SS}$, brazing seam and $\mathrm{Mn}-\mathrm{Cu}$ alloy. The brazing seam was composed of a grey matrix phase and a white phase distributed at the grain boundary of matrix phase. And there were needle-like compounds distributed near the interfaces of both SS/brazing seam and $\mathrm{Mn}-\mathrm{Cu} /$ brazing seam (the blue arrows pointed areas in Fig. 4(a)).

The microstructure of SS/brazing seam interface region is presented in Fig. 4(b), and the EDS analysis results of points in Fig. 4(b) are listed in Table 6. The results show that a (Fe, $\mathrm{Mn}$ ) solid solution diffusion layer with small amounts of $\mathrm{Cu}, \mathrm{Cr}$ and $\mathrm{Ni}$ (point 1) was formed between SS and brazing seam. According to $\mathrm{Fe}-\mathrm{Mn}$ and $\mathrm{Fe}-\mathrm{Cu}$ phase diagrams, $\mathrm{Mn}$ is completely soluble in $\mathrm{Fe}$ and the solubility of $\mathrm{Cu}$ in $\mathrm{Fe}$ is low. Therefore, the diffusion distance of Mn in SS was longer than that of $\mathrm{Cu} .^{13)}$ The formation of solid solution diffusion layer indicated that the bonding between SS and brazing seam was strong. However, the mismatch of linear expansion coefficient between SS and brazing seam led to the high residual stress at the interface region. As a result, the microcracks were formed at the interface. ${ }^{17,18)}$ In brazing seam, the grey matrix phase (point 2, 4 and 5) was $(\mathrm{Cu}, \mathrm{Mn}$ ) solid solution with varying content of $\mathrm{Sn}, \mathrm{Ni}, \mathrm{Fe}$ and $\mathrm{Cr}$. And the white phase (point 3) was $(\mathrm{Cu}, \mathrm{Mn}, \mathrm{Sn})$ solid solution which contained higher $\mathrm{Sn}$ and lower Mn compared to the matrix phase. The high content of $\mathrm{Sn}$ in white phase was also directly confirmed by the distribution feature of $\mathrm{Sn}$ element in Fig. 4(c). The white phase has a lower melting point and solidified at the grain boundary of matrix phase during cooling process. What's more, the matrix phase, which
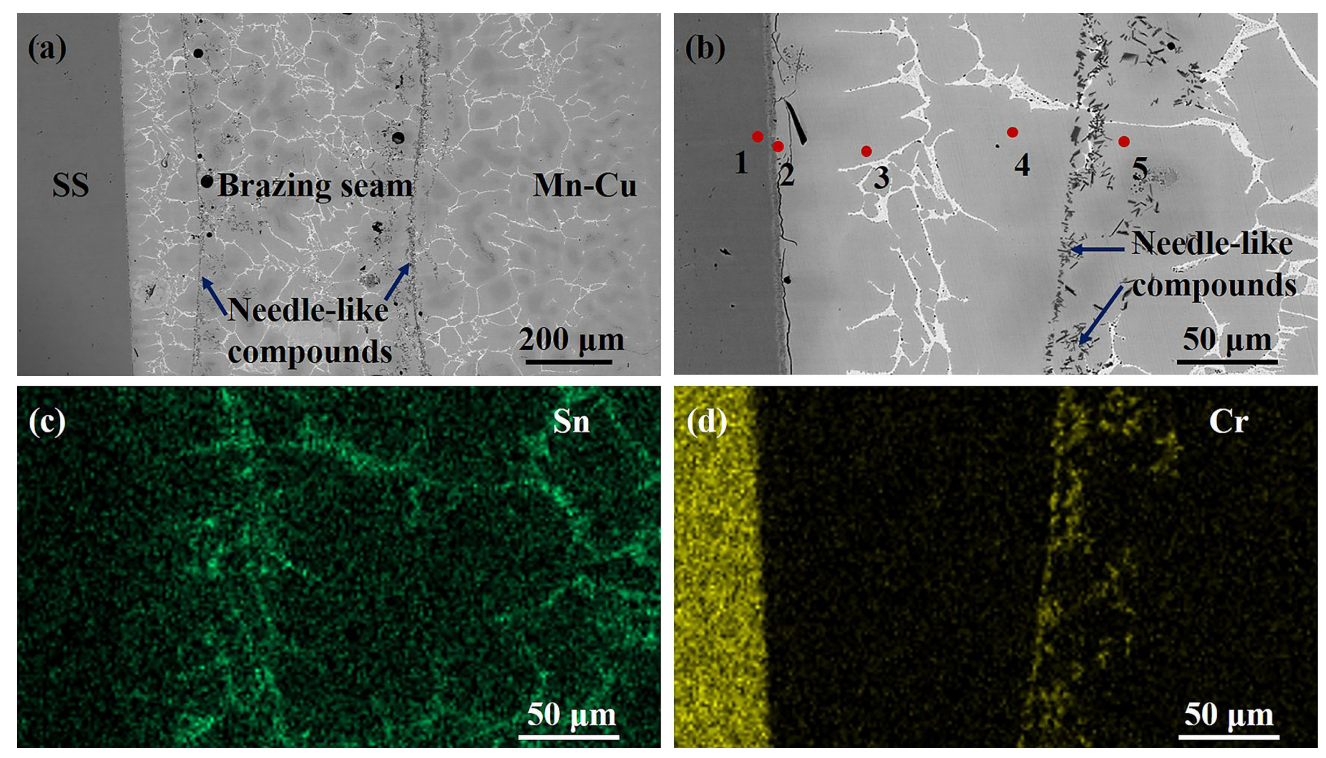

Fig. 4 BSE images of the microstructure of (a) $\mathrm{Mn}-\mathrm{Cu} / \mathrm{SS}$ joint brazed at $870{ }^{\circ} \mathrm{C}$ for 10 min and (b) the interface region of SS/brazing seam, surface scan of $\mathrm{Sn}(\mathrm{c})$ and $\mathrm{Cr}(\mathrm{d})$ of (b). 
Table 6 EDS analysis results of points marked in SS/brazing seam interface region in Fig. 4(b) (mass\%).

\begin{tabular}{cccccccccc}
\hline Points & $\mathrm{Fe}$ & $\mathrm{Cr}$ & $\mathrm{Mn}$ & $\mathrm{Cu}$ & $\mathrm{Ni}$ & $\mathrm{Sn}$ & $\mathrm{Al}$ & $\mathrm{Si}$ & $\mathrm{Zn}$ \\
\hline 1 & 25.30 & 4.63 & 62.26 & 5.92 & 1.14 & 0.07 & 0.41 & 0.12 & 0.15 \\
2 & 0.85 & 0.28 & 48.06 & 45.67 & 2.06 & 1.41 & 0.61 & 0.00 & 1.05 \\
3 & 0.32 & 0.04 & 32.53 & 50.40 & 1.46 & 13.37 & 0.55 & 0.00 & 1.33 \\
4 & 1.07 & 0.29 & 47.56 & 45.50 & 2.30 & 1.85 & 0.58 & 0.00 & 0.86 \\
5 & 1.34 & 0.47 & 49.99 & 42.83 & 2.31 & 1.57 & 0.65 & 0.02 & 0.82 \\
\hline
\end{tabular}

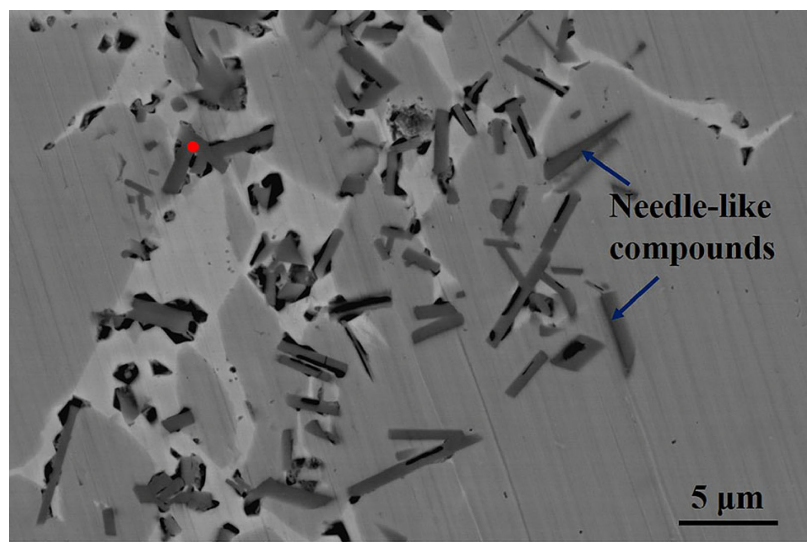

Fig. 5 BSE image of the needle-like compounds in the brazing seam of $\mathrm{Mn}-\mathrm{Cu} / \mathrm{SS}$ joint.

contained a small amount of $\mathrm{Sn}$, was distributed adjacent to the SS, therefore, no intermetallic compounds of Sn were formed at the interface of SS/brazing seam. According to the distribution feature of $\mathrm{Cr}$ element, as shown in Fig. 4(d), the needle-like compounds distributed near the interface of $\mathrm{SS} /$ brazing seam were rich in $\mathrm{Cr}$. Since there was no $\mathrm{Cr}$ in the designed filler metal, the formation of these needle-like compounds should be attributed to the dissolution of SS substrate.

Figure 5 shows the microstructure of needle-like compounds distributed in brazing seam. It can be seen that the interface between the compounds and the phases in brazing seam was sharp. The EDS results showed that the compound (marked by red point in Fig. 5) contained 62.74 mass\% Mn, 16.98 mass \% Cr, 10.69 mass\% $\mathrm{Cu}$ and 5.37 mass\% Fe with little amount of $\mathrm{Sn}, \mathrm{Ni}$ and $\mathrm{Zn}$. Therefore, it should be the compound of $\mathrm{Mn}-\mathrm{Cr}-\mathrm{Cu}-\mathrm{Fe}$. During the brazing process, the elements of SS such as $\mathrm{Fe}$ and $\mathrm{Cr}$ dissolved into the liquid filler metal, and resulted in the formation of the needle-like $\mathrm{Mn}-\mathrm{Cr}-\mathrm{Cu}-\mathrm{Fe}$ compounds. The solidification of liquid filler metal usually started from the interface regions of substrates and filler metal, therefore, the compounds mostly distributed near the interface regions in brazing seam.

At the $\mathrm{Mn}-\mathrm{Cu}$ alloy side, the $(\mathrm{Cu}, \mathrm{Mn}, \mathrm{Sn})$ solid solution phase penetrated in the grain boundaries of $\mathrm{Mn}-\mathrm{Cu}$ alloy, which caused local melting of $\mathrm{Mn}-\mathrm{Cu}$ alloy. The melted alloy entered the liquid filler metal. As a result, the Mn content of $(\mathrm{Cu}, \mathrm{Mn})$ solid solution matrix phase in brazing seam was

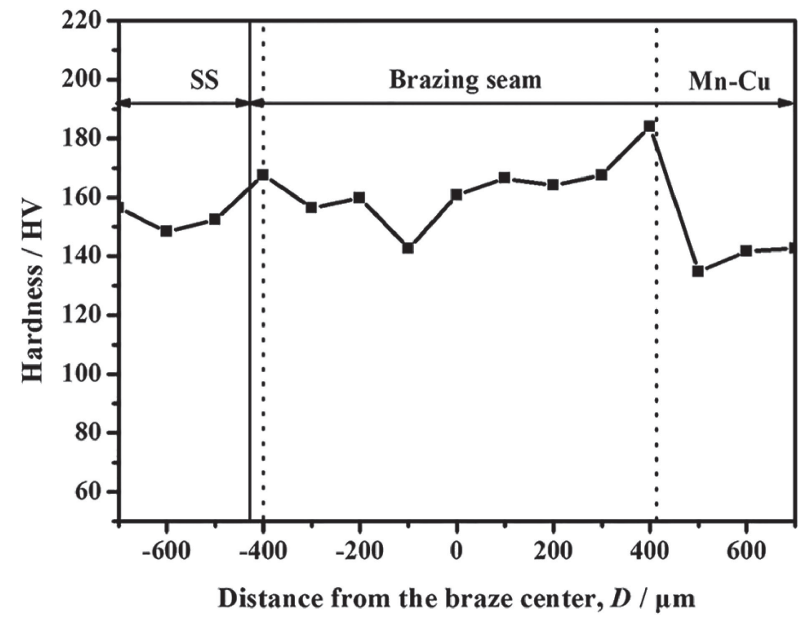

Fig. 6 The microhardness of $\mathrm{Mn}-\mathrm{Cu} / \mathrm{SS}$ joint brazed at $870{ }^{\circ} \mathrm{C}$ for $10 \mathrm{~min}$.

higher than that of the designed filler metal, and the width of brazing seam was increased. Due to the similar element compositions of $\mathrm{Mn}-\mathrm{Cu}$ alloy and filler metal, the epitaxial solidification was observed between brazing seam and Mn$\mathrm{Cu}$ alloy. There was no clear boundary between brazing seam and $\mathrm{Mn}-\mathrm{Cu}$ alloy.

Microhardness profile is a good indicator of the joint's microstructure. Figure 6 shows the microhardness distribution feature of $\mathrm{Mn}-\mathrm{Cu} / \mathrm{SS}$ joint brazed at $870{ }^{\circ} \mathrm{C}$ for $10 \mathrm{~min}$. Their average hardness was $152 \mathrm{HV}$ and $140 \mathrm{HV}$ for SS and $\mathrm{Mn}-\mathrm{Cu}$ alloy, respectively. Due to the solution strengthening of $\mathrm{Mn}$ and $\mathrm{Sn}$, the hardness of brazing seam was close to that of SS substrate. But the middle region of brazing seam has relatively low hardness. What's more, the regions where needle-like $\mathrm{Mn}-\mathrm{Cr}-\mathrm{Cu}-\mathrm{Fe}$ compounds distributed (marked by the dotted lines in Fig. 6) showed the highest hardness value of about $184 \mathrm{HV}$. The size of needle-like $\mathrm{Mn}-\mathrm{Cr}-$ $\mathrm{Cu}-\mathrm{Fe}$ compounds was much smaller than the size of indentation, it might be the high hardness of compounds resulted in the high hardness of their distributed regions.

\subsection{Shear strength of brazed joints}

Figure 7 shows the shear strength of $\mathrm{Mn}-\mathrm{Cu} / \mathrm{SS}$ joints brazed at different brazing temperatures for different times. In Fig. 7(a), as the brazing temperature increased from $850{ }^{\circ} \mathrm{C}$ to $870{ }^{\circ} \mathrm{C}$, the shear strength of brazed joints increased from $173 \mathrm{MPa}$ to $212 \mathrm{MPa}$. However, the shear strength of joints 

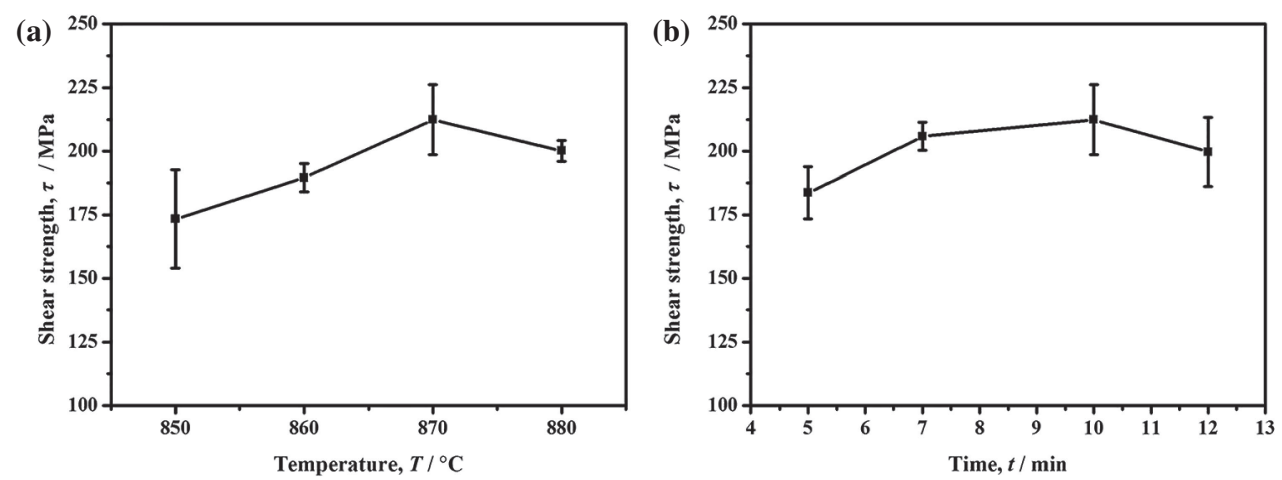

Fig. 7 Shear strength of joints brazed at different brazing temperatures (a) for different holding times (b).
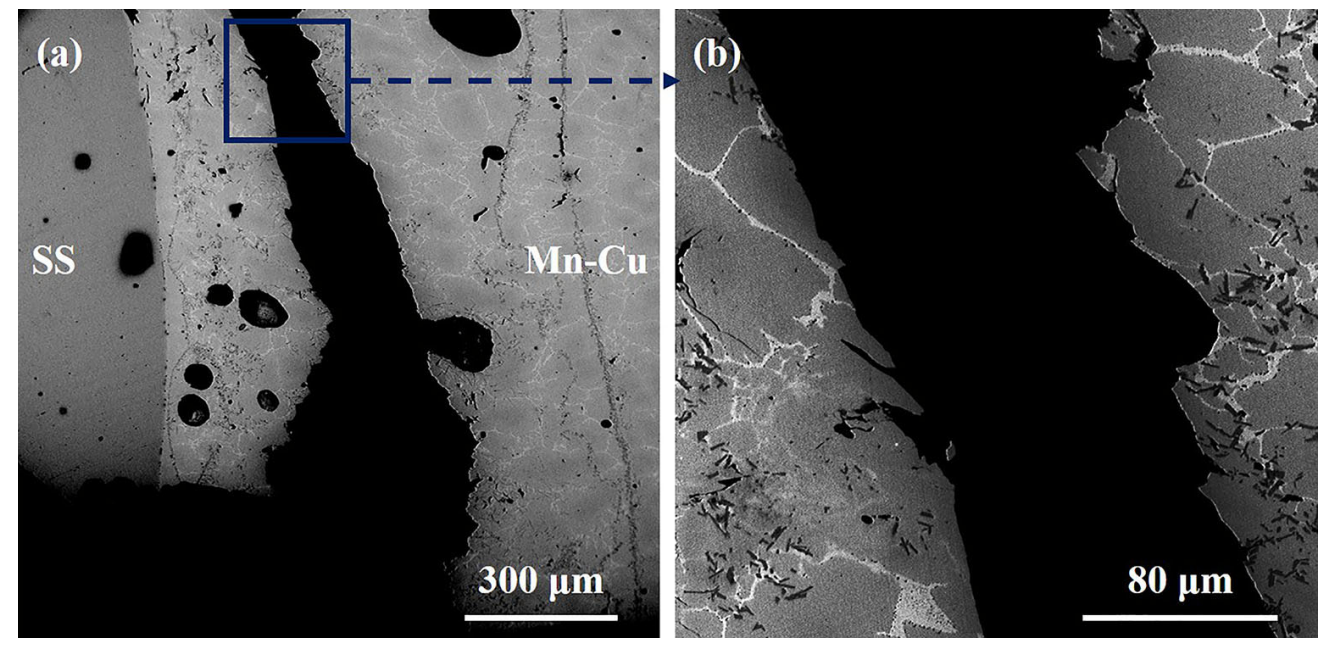

Fig. 8 BSE images of the fractured joint.
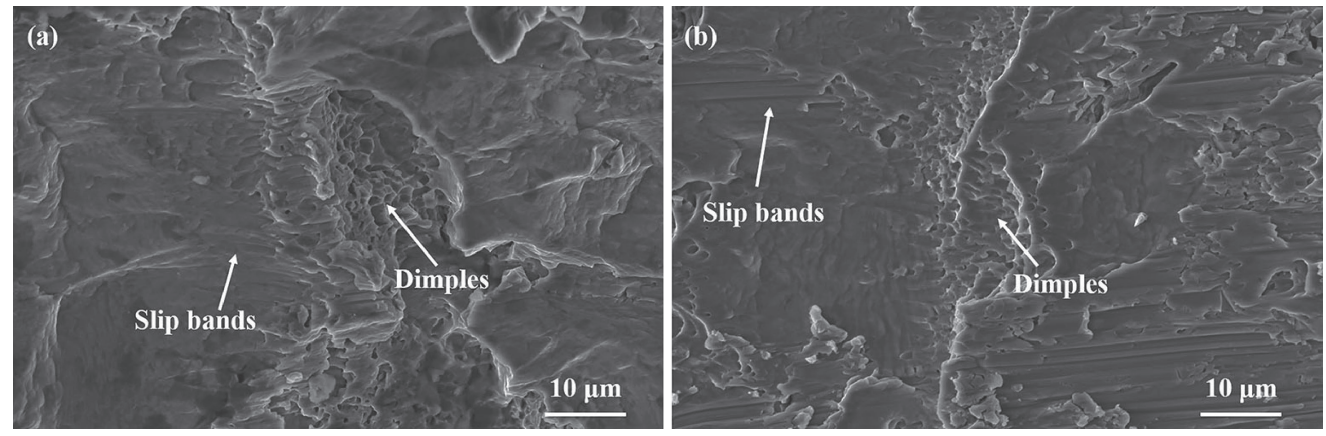

Fig. 9 Fracture surfaces of the brazed joint, (a) 430SS side, (b) Mn-Cu alloy side.

reduced to $200 \mathrm{MPa}$ as the brazing temperature increased to $880^{\circ} \mathrm{C}$. In Fig. 7(b), the shear strength of brazed joints increased gradually as the time increased from $5 \mathrm{~min}$ to $10 \mathrm{~min}$ at $870^{\circ} \mathrm{C}$, but the strength value decreased as the holding time extended to $10 \mathrm{~min}$. Figure 8 shows the fractural position of joint brazed at $870{ }^{\circ} \mathrm{C}$ for $10 \mathrm{~min}$. It can be seen that the fracture mainly occurred at the middle of brazing seam. The slip bands and dimples were observed in the fracture surfaces in Fig. 9, which demonstrated that the joint exhibited the ductile fracture characteristic. The EDS analysis results show that the $(\mathrm{Cu}, \mathrm{Mn})$ matrix phase at the middle of brazing seam has lower Mn content. This illustrated that the microstructure of brazing seam was inhomogeneous. The microhardness results in Fig. 6 also indicated that the middle region of brazing seam was weaker in the joint. Therefore, the joint fractured at the middle region of brazing seam during shear test.

Figure 10 presents the microstructures of $\mathrm{Mn}-\mathrm{Cu} / \mathrm{SS}$ joints brazed at different temperatures. With the increase of brazing temperature, the brazing seam became wider due to the increased melting quantity of $\mathrm{Mn}-\mathrm{Cu}$ alloy. The widening of brazing seam aggravated the inhomogeneity of microstructure. When the brazing temperature lower than $870{ }^{\circ} \mathrm{C}$, although the brazing seam was widening, element $\mathrm{Mn}$ dissolved from the melted $\mathrm{Mn}-\mathrm{Cu}$ alloy strengthened the brazing seam. Therefore, the shear strength of brazed joints was increased gradually. However, at higher temperature, the excessive melting of $\mathrm{Mn}-\mathrm{Cu}$ alloy not only led to the further 

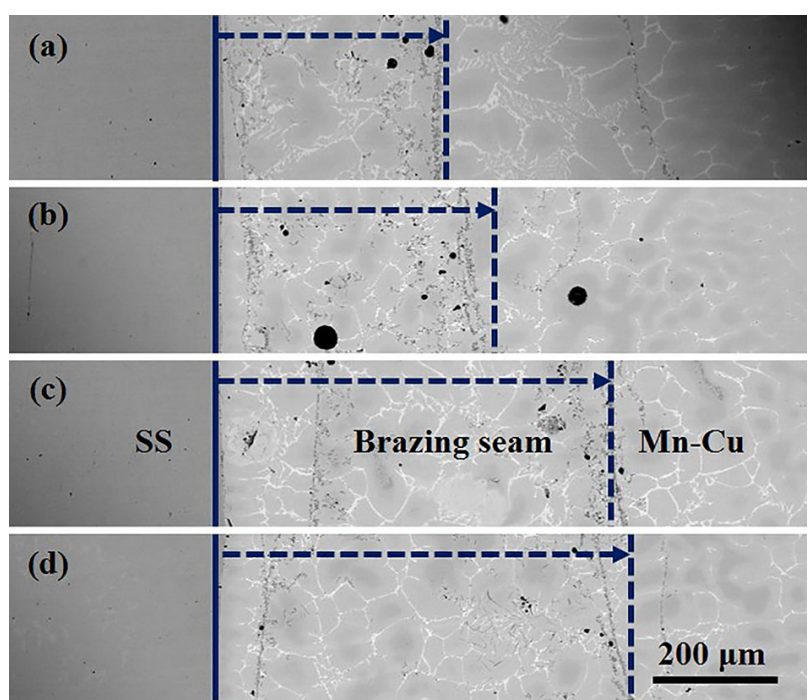

Fig. 10 BSE images of $\mathrm{Mn}-\mathrm{Cu} / \mathrm{SS}$ joints brazed at different temperatures, (a) $850{ }^{\circ} \mathrm{C}$, (b) $860{ }^{\circ} \mathrm{C}$, (c) $870^{\circ} \mathrm{C}$, (d) $880^{\circ} \mathrm{C}$.

widening of brazing seam but also caused the coarsen of grains in the brazing seam. As a result, the strength of brazing seam decreased accordingly. ${ }^{19}$ ) The effect of holding time on the shear strength of brazed joints was similar with that of brazing temperature.

\section{Conclusions}

In this work, the brazing of $\mathrm{Mn}-\mathrm{Cu}$ damping alloy and 430SS using a $\mathrm{Cu}-34 \mathrm{Mn}-6 \mathrm{Ni}-10 \mathrm{Sn}$ filler metal was carried out. The following conclusions can be drawn.

(1) The $\mathrm{Cu}-34 \mathrm{Mn}-6 \mathrm{Ni}-10 \mathrm{Sn}$ filler metal was composed of two $(\mathrm{Cu}, \mathrm{Mn})$ solid solution with different $\mathrm{Sn}$ content, and the melting point of the filler metal was $819^{\circ} \mathrm{C}$.

(2) $\mathrm{A}(\mathrm{Fe}, \mathrm{Mn})$ solid solution diffusion layer was formed at the interface of SS/brazing seam. The brazing seam was composed of a $(\mathrm{Cu}, \mathrm{Mn})$ matrix solid solution phase and a $(\mathrm{Cu}, \mathrm{Mn}, \mathrm{Sn})$ solid solution phase. Besides, some needle-like $\mathrm{Mn}-\mathrm{Cr}-\mathrm{Cu}-\mathrm{Fe}$ compounds were formed near the interface of each substrate and brazing seam. The melting of $\mathrm{Mn}-\mathrm{Cu}$ alloy has great effect on the microstructure of brazing seam.

(3) With the increase of brazing temperature and holding time, the shear strength of $\mathrm{Mn}-\mathrm{Cu} / \mathrm{SS}$ brazed joint increased at first and then decreased. The joint brazed at
$870{ }^{\circ} \mathrm{C}$ for $10 \mathrm{~min}$ showed the highest shear strength of about $212 \mathrm{MPa}$. The joint fractured at the middle of brazing seam, and the fracture showed ductile fracture characteristic.

\section{Acknowledgment}

This work was supported by the National Natural Science Foundation of China (Grant No. 11172248 and No. 51701167) and the Fundamental Research Funds for the Central Universities (Grant No. 2682017CX073).

\section{REFERENCES}

1) F. Yin, K. Nagai, K. Watanabe and K. Kawahara: Mater. Trans. 44 (2003) 1671-1674.

2) P. Venkateswararao and D.K. Chatterjee: J. Mater. Sci. 15 (1980) 139_ 148.

3) W. Liu, N. Li, Z. Zhong, J. Yan, D. Li, Y. Liu, X. Zhao and S. Shi: Mater. Des. 106 (2016) 45-50.

4) D. Li, W. Liu, N. Li, J. Yan and S. Shi: Adv. Eng. Mater. 19 (2017) 1700437.

5) M.J. Carmezim, A.M. Simões, M.F. Montemor and M.D. Cunha Belo: Corros. Sci. 47 (2005) 581-591.

6) R.B. Chen and R.K. Shiue: J. Mater. Sci. Lett. 20 (2001) 1435-1437.

7) R.K. Choudhary, A. Laik and P. Mishra: J. Mater. Eng. Perform. 26 (2017) 1085-1100.

8) T. Venkateswaran, V. Xavier, D. Sivakumar, B. Pant and J.G.D. Ram: Mater. Des. 121 (2017) 213-228.

9) Y. Zheng, N. Li, J. Yan and Y. Cao: Mater. Sci. Eng. A 661 (2016) 2531.

10) P.S. Gawde, R. Kishore, A.L. Pappachan, G.B. Kale and G.K. Dey: Trans. Indian Inst. Met. 63 (2010) 853-857.

11) R.K. Roy, A.K. Panda, S.K. Das, Govind and A. Mitra: Mater. Sci. Eng. A 523 (2009) 312-315.

12) H.S. Na, J.K. Kim, B.Y. Jeong and C.Y. Kang: Met. Mater. Int. 13 (2007) 511-515.

13) R.K. Roy, S. Singh, M.K. Gunjan, A.K. Panda and A. Mitra: Fusion Eng. Des. 86 (2011) 452-455.

14) T. Venkateswaran, T. Thinesh Babu, M. Agilan, D. Sivakumar, B. Pant and D.P. Sudhakar: Mater. Sci. Forum 830-831 (2015) 253-256.

15) M.G. Li, D.Q. Sun, X.M. Qiu and S.Q. Yin: Mater. Sci. Technol. 21 (2005) 1318-1322.

16) S.K. Chatterjee, Z. Mingxi and A.C. Chilton: Weld. J. 70 (1991) S118S122.

17) H. Sabetghadam, A.Z. Hanzaki, A. Araee and A. Hadian: J. Mater. Sci. Technol. 26 (2010) 163-169.

18) O. Yilmaz and M. Aksoy: J. Mater. Process. Technol. 121 (2002) 136142.

19) M. Swathi Kiranmayee, A.K. Jha, S.K. Manwatkar, D.P. Sudhakar, P. Ramesh Narayanan, K. Sreekumar and P.P. Sinha: Mater. Sci. Forum 710 (2012) 650-655. 